\title{
IS SOCIETY STILL SHACKLED WITH THE CHAINS OF A 1993 ENGLAND?: CONSENT, SADO-MASOCHISM AND $R$ V BROWN
}

\author{
JORDAN MOULDS
}

Sadomasochism has traditionally been categorised as a deviant sexual desire, painted with the same brush of immorality that was applied to homosexuality and transvestism for decades. It has been denounced, not only by society, but also by the medical profession and the judiciary. In $\mathrm{R} v$ Brown, the House of Lords highlighted society's revulsion for such practices and refused, as an issue of public policy, to allow consent to be raised as a defence by those who engage in such activities. In the 22 years since the decision, however, the weight placed on the protection of our bodily autonomy and freedom of sexual expression has significantly increased. The applicability of $\mathrm{R} \mathrm{v}$ Brown in light of these changes is yet to be considered in Australia with any binding authority. This article seeks to provide readers with an insight into the likely outcome of an attempt to prosecute those who, in 2015, engage in sadomasochism. Ultimately, this article concludes that as a result of $s 22$ of the Criminal Law Consolidation Act 1935 (SA), construed in light of the increased value placed on protecting bodily autonomy, sexual self-determination and the preservation of privacy, a South Australian court, and to a lesser extent, all Australian courts, would recognise the consent of those who sustain harm in the pursuit of pain-induced pleasure.

\section{CONTENTS}

I

Introduction

II Common Law Position - England and Wales .............................................................. 76

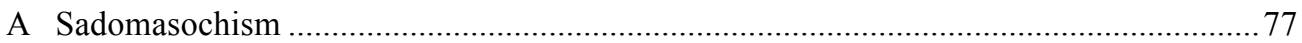

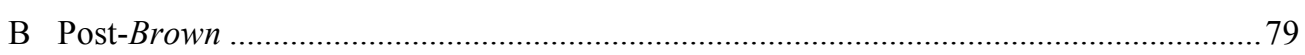

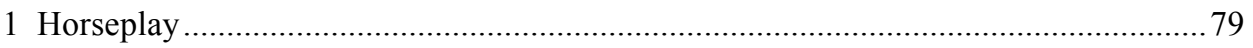

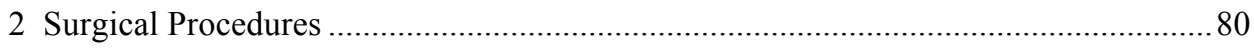

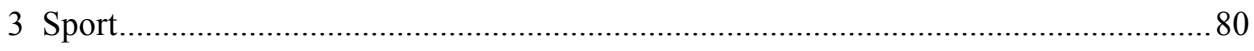

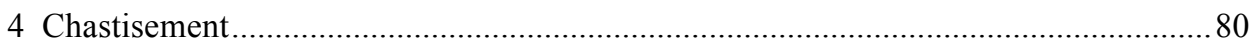

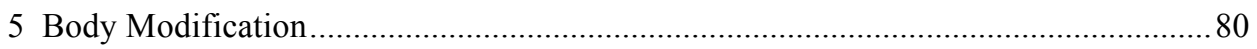

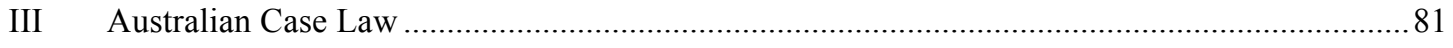

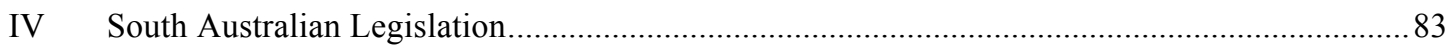

LLB student, School of Law, University of South Australia. 


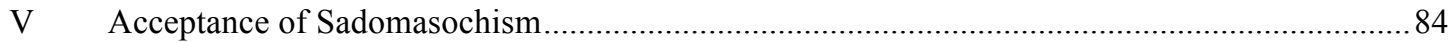

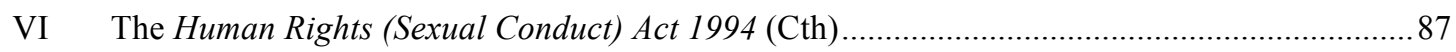

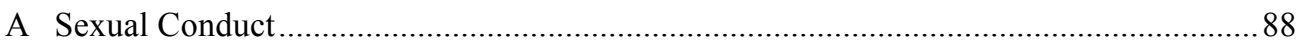

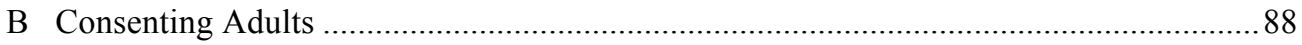

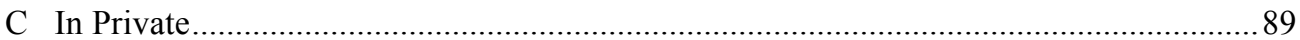

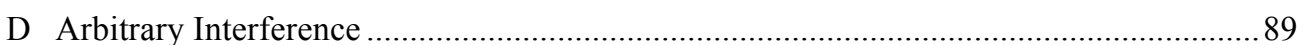

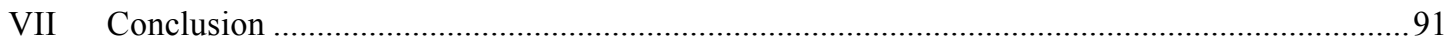

\section{INTRODUCTION}

As early as the $19^{\text {th }}$ century, courts have been prepared to recognise that a person's right to bodily autonomy is not absolute; it is inherently bound by the necessary limits that are imposed to protect society. The interaction between these limits and providing consent to harm was first explored by Stephen $\mathrm{J}$ in $R v$ Coney, ${ }^{1}$ who held that prize fighting was injurious to the public and that harm sustained during activities so injurious could not give rise to consent as a defence. ${ }^{2}$ A series of English cases established a number of common law exceptions to this general rule in the interest of preserving autonomy in discrete, but limited, circumstances. However, the general proposition that injuries amounting to actual bodily harm or greater could not be consented to as a matter of public policy, remained. ${ }^{3}$

The application of this proposition to sadomasochistic conduct was notoriously considered in $R v$ Brown, ('Brown') where Lord Templeman declined to afford any exception to sadomasochism and described it as a 'cult of violence' against which society was 'bound to protect itself.' ${ }^{4}$ In making such a determination, the majority declined to recognise the sexual autonomy of the defendants and instead preferred to adopt the role of paternalistic protectors of society; a move which has been criticised as an unjustifiable

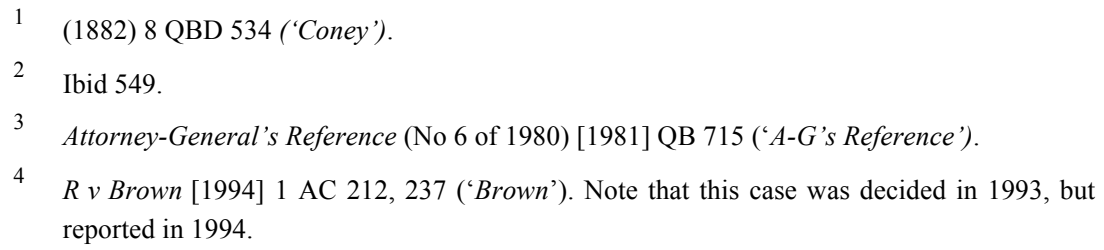


limit on autonomy. ${ }^{5}$ The applicability of such a precedent in Australia, however, is yet to be judicially explored with any binding authority. The purpose of this article is to provide readers with an insight into the likely outcome of prosecutions against those who, in modern Australia, engage in sadomasochism, and to explore the issues underpinning such an outcome.

Part II of this article gives an overview of the case law which forms the English authority on the issue, including any developments post-Brown. Parts III and IV then go on to examine the limited case law in Australia and provide an overview of the South Australian provisions contained in s 22 of the Criminal Law Consolidation Act 1935 (SA) ('CLCA'). Part V deals with the crucial question of prevalence and acceptance of sadomasochism in modern Australia, drawing on empirical studies and popular culture. Part VI then examines in some detail, the applicability of the Human Rights (Sexual Conduct) Act 1994 (Cth), which leads to a discussion of the level of harm at which consent should no longer be recognised. This article argues that a modern society, which has radically transformed since 1993, will give legal effect to the consent of those who engage in sadomasochism.

\section{Common Law Position - England And WaLeS}

The courts have, without any controversy, long upheld the logical necessity that 'an assault with consent is no assault at all, ${ }^{, 6}$ not because consent can be construed as a valid defence to common assault, but because its absence must be established as an element of the crime by the prosecution before any action can succeed. ${ }^{7}$ Such an element is not required to prosecute a defendant successfully for recklessly or intentionally causing harm or serious harm in South Australia, ${ }^{8}$ and so consent must therefore be construed instead as a defence to a charge. In these circumstances, courts generally favour restricting the use of consent as a defence on the basis that there are certain activities and/or levels of harm from which the judiciary are trusted to protect

7 This is made clear in South Australia under the Criminal Law Consolidation Act 1935 (SA), s 20(1). 
us as a matter of public policy. ${ }^{9}$ This point was highlighted by Stephen $\mathrm{J}$ in Coney, who stated that:

the consent of the person who sustains injury is no defence to the person who inflicts the injury, if the injury is of such a nature, or is inflicted under such circumstances, that its infliction is injurious to the public as well as the person injured. ${ }^{10}$

Together with Coney, a handful of later authorities including AttorneyGeneral's Reference (No 6 of 1980) (' $A-G$ 's Reference') reaffirmed that outside the exceptions discussed below, the relevant limit at or above which consent is not a defence was 'actual bodily harm' ('ABH'). ${ }^{11}$ The limit of actual bodily harm was defined in $R v$ Donovan $^{12}$ as being 'more than merely transient or trifling', but not needing to be permanent. ${ }^{13} \mathrm{ABH}$ was helpfully summarised by the NSW Court of Criminal Appeal in McIntyre $v R^{14}$ as being 'something less than 'grievous bodily harm', which by contrast requires 'really serious physical injury.' The Court suggested that 'scratches and bruises to a victim are typical examples of injuries capable of amounting to actual bodily harm'. ${ }^{15}$ This definition of $\mathrm{ABH}$ highlights just how low the threshold was set; in essence, any injury that leaves the subject of an assault with any physical manifestation of that assault, which is not transient or trifling, will amount to harm which is incapable of being consented to.

\section{A Sadomasochism}

The application of this general proposition to sadomasochistic conduct was considered in Brown. However, before Brown reached the House of Lords, the Court of Appeal was tasked with considering consent to sadomasochism in $R v$ Boyea, ${ }^{16}$ a case in which the victim sustained substantial internal vaginal injuries. The Court of Appeal applied Coney and $A-G$ 's Reference, decided that sadomasochism was not one of the excepted circumstances, and held that consent could not be accepted because the injuries sustained were

9 Model Criminal Code Officers Committee of the Standing Committee of Attorneys-General, Model Criminal Code 2009, 119.

10

Coney (1882) 8 QBD 534, 549; Brown [1994] 1 AC 212, 231.

11 See $A$-G's Reference [1981] QB 715; $R$ v Aitken [1992] 1 WLR 1066; $R v$ Jones [1887] Crim LR 123.

$12 \quad R v$ Donovan [1934] 2 KB 498.

13 Ibid 509.

14 McIntyre v R [2009] NSWCCA 305.

15 Ibid [44].

16 (1992) 156 JPR 505. 
greater than actual bodily harm. The Court noted, however, that while the acceptable 'level of vigour' used in the course of sexual intercourse had increased over time since 1934, it had not increased so far as to provide a defence in that case. ${ }^{17}$

When Operation Spanner, which sought to stamp out illegal 'snuff' pornography, uncovered a video depicting a group of homosexual males inflicting severe injuries on each other, ${ }^{18}$ the defendants were each charged with $\mathrm{ABH}$ and came before the trial court as $R v$ Brown. The trial judge ruled that consent was not available as a defence to the charges and this ruling was upheld on appeal. The defendants subsequently appealed to the House of Lords, which was asked to decide whether sadomasochistic conduct could earn itself a position on the podium of exceptions, or whether it would reaffirm the threshold of $\mathrm{ABH}$.

The House of Lords, by a 3-2 majority, did not depart from the established threshold of actual bodily harm, nor did they deem that derivation of sexual pleasure through pain was a genuine pursuit which justified allowing consent as a defence. Lord Templeman was not prepared to 'invent a defence of consent for sadomasochistic encounters which breed and glorify cruelty' ${ }^{19}$ To Lord Templeman, pleasure derived from the infliction of pain was an evil thing against which society 'is entitled and bound to protect itself. ${ }^{20}$ The majority did not see any social utility in inflicting 'actual bodily harm during the course of homosexual sadomasochistic activities'. ${ }^{21}$ In strong dissent, however, Lord Mustill argued that what consenting adults did in private was not a matter for judicial interference and recast the limit at which consent would not be available as grievous bodily harm ('GBH'). ${ }^{22} \mathrm{GBH}$ can be

17 Ibid 519.

18 The sadomasochistic conduct for which the defendants were convicted included activities such as the nailing of each other's foreskin and scrotums to a board of wood, the insertion of hot wax into each other's urethra followed by the burning of each other's penises with a candle, and the incising of each other's scrotums with a scalpel to the effusion of blood: Brown [1994] 1 AC 212, 246 (Lord Jauncey).

19 Brown [1994] 1 AC 212, 236.

$20 \quad$ Ibid 237.

21 Ibid 246.

22 Ibid 258. 
contrasted against $\mathrm{ABH}$ on the basis of being more severe than $\mathrm{ABH},{ }^{23}$ and applies only to 'really serious bodily harm'. ${ }^{24}$

When Brown was appealed to the European Court of Human Rights ('ECHR') as Laskey $v$ United Kingdom, ${ }^{25}$ on the basis that the decision may have constituted an interference with the private lives of those involved, the ECHR held that the decision was justified in the interest of protecting public health.

\section{B Post-Brown ${ }^{26}$}

When consensual sadomasochistic activity was the subject of an appeal to the Court of Appeal in $R v$ Emmett, ${ }^{27}$ the majority decision in Brown was followed, leaving Lord Mustill's dissent to fall by the wayside. Therefore, entering the $21^{\text {st }}$ century, the position in England and Wales was that consent cannot be raised as a defence where the conduct causes actual bodily harm (or greater) in the pursuit of sexual gratification by one or both participants. The general limit of $\mathrm{ABH}$ has been set aside, however, only where the courts have recognised some form of ostensible benefit to the participants and the public at large emanating from the activities. The relevant exceptions to the general rule are summarised below.

\section{Horseplay}

One such excepted category is 'horseplay'. In $R v$ Jones, ${ }^{28}$ young schoolboys who were convicted of inflicting grievous bodily harm on their schoolmates were, on appeal, afforded a defence of consent. The Court held that rough and undisciplined horseplay possessed ostensible benefit and decided that it was not the province of the court to invalidate such conduct. This was followed contentiously in $R v$ Aitken, ${ }^{29}$ where convictions against three RAF

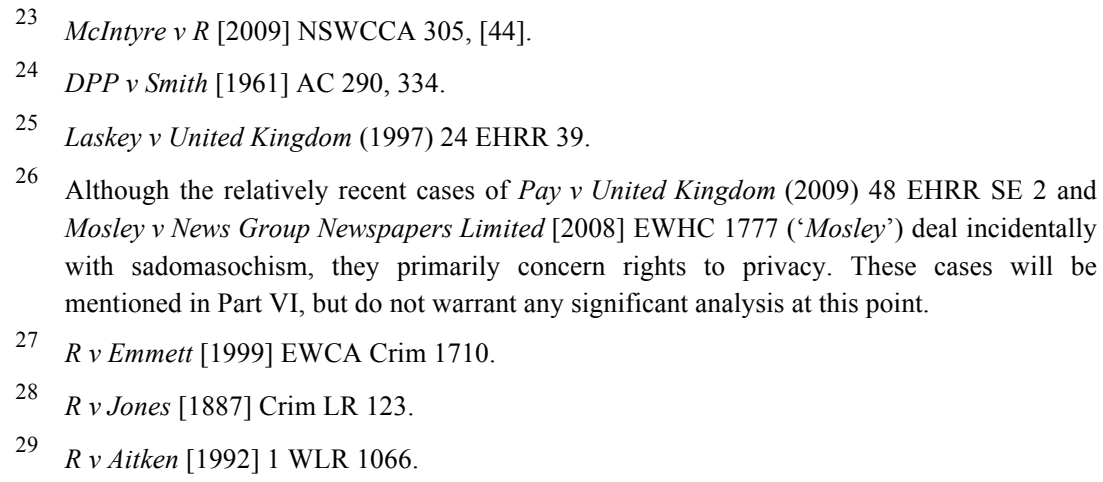


airmen accused of setting light to their colleague were quashed on the basis that consent should have been available as a defence.

\section{Surgical Procedures}

It does not require any more than a superficial mention that the defence of consent is open to a medical professional carrying out surgery which goes beyond common assault, in order to allow that surgery to be carried out properly. $^{30}$

\section{Sport}

In Coney, Stephen $\mathrm{J}$ noted that although the consent of contestants in prize fights offers no valid defence, the consent of those who participate in properly conducted sports and games will, in contrast, be recognised. ${ }^{31}$ This was on the basis of the significant benefit that can be enjoyed by the public from properly conducted sport, even where assault that comes within the rules of the game ensues. ${ }^{32}$ This was further substantiated in Pallante $v$ Stadiums Pty $L t d{ }^{33}$ where it was held that even in light of the intentionally violent nature of boxing, the question of consent can still be put to the jury.

\section{Chastisement ${ }^{34}$}

In 1860, Lord Cockburn CJ held in $R v$ Hopley ${ }^{35}$ that, although the chastisement causing death of the pupil in that case could not be consented to, there nonetheless existed a valid defence in situations where reasonable and moderate corporal punishment is inflicted for the purpose of 'correcting what is evil in the child'. ${ }^{36}$

\section{Body Modification}

Consent to undergoing body modification was considered in $R v$ Wilson, ${ }^{37}$ a case in which the defendant used a hot knife to brand his initials on the

See Attorney-General's Reference [1981] QB 715, 719.

31

Coney (1882) 8 QBD 534, 549-550.

32 Pallante v Stadiums Pty Ltd [1976] VR 331.

33 Ibid.

34 It is unlikely that in modern Australia such a defence would be available to any person other than the parents of that child.

$35 R$ v Hopley (1860) 2 F\&F 202; 175 ER 1024.

36 Ibid 204.

$37 \quad R v$ Wilson [1996] 3 WLR 125. 
buttocks of his wife. Crucially, this case was decided post-Brown. The Court purported to distinguish Brown and held that the wife's consent was a complete defence on the grounds that Brown was concerned with a distinguishably extreme factual scenario and that the exercise of bodily autonomy associated with undergoing body transformations provided a sufficient public benefit. The Court was reluctant to intervene in relations between husbands and wives: '[c]onsensual activity between husband and wife, in the privacy of the matrimonial home, is not, in our judgment, normally a proper matter for criminal investigation, let alone criminal prosecution'. ${ }^{38}$ It was held that, although gratification may have been incidental, the primary purpose of the conduct was bodily adornment and on this basis, consent could give rise to a valid defence.

\section{Australian CASE LAW}

To ascertain the status of sadomasochistic conduct in contemporary Australia, the application of the authorities from England and Wales in the body of Australian case law must be considered. Unfortunately, its application is severely limited, with no binding authority from the High Court of Australia, and indeed, little direct authority on point from any court in Australia.

When the question of consent to assault occasioning actual bodily harm arising out of a fistfight came before the Queensland Court of Criminal Appeal in $R v$ Raabe, ${ }^{39}$ the Court adopted the threshold of $\mathrm{ABH}$, but suggested that the consent of participants to a fistfight could be recognised as a defence. This decision was applied by the same Court six years later in Lergesner $v$ Carroll $^{40}$ where fist-fighting was unanimously held to give rise to the availability of consent as a defence. This decision, however, has been criticised, ${ }^{41}$ and is likely to be limited by the Queensland legislation which it interpreted.

The two leading Australian cases dealing with sadomasochistic harm, $R v$ Stein ('Stein') ${ }^{42}$ and $R v$ McIntosh ('McIntosh'), ${ }^{43}$ arose in the superior courts

38 Ibid 128.

$39 \quad R v$ Raabe [1985] 1 Qd R 115.

40 Lergesner $v$ Carroll [1991] 1 Qd R 206.

41 George Syrota, 'Consensual Fist Fights and Other Brawls: Are They a Crime?' (1996) 6 WA Criminal Law Forum 169.

$42 \quad R v$ Stein (2007) 18 VR 376. 
of Victoria. Both of these cases dealt with sadomasochistic conduct that unintentionally caused the death of one participant; a fact that necessarily elicits the discussion of vastly different policy concerns and the principle of autonomy. The comments that were made in both cases nevertheless provide an insight into Australia's current position.

In 1999, Vincent $\mathrm{J}$ in $R v$ McIntosh summarised what he believed to be the position in Australia, England and Canada, which was later adopted by Kellam JA in 2007 in $R v$ Stein:

First, it is not, of itself ... contrary to the law of this jurisdiction to engage in activities that could be described as bondage or sexual sadomasochism.

Second, the possibility that an activity involves the application of physical force and is accompanied by a real risk of even quite serious injury does not, of itself, render that activity unlawful.

Third, apart from some special circumstances which the law has guarded carefully, and which are not present here, no recognition will be accorded to the consent of an individual to the infliction of significant physical injury upon himself or herself. ${ }^{44}$

While the first of these three limbs makes it clear that sadomasochism, in and of itself, is not illegal (which is to say that there exists no law that expressly prohibits the derivation of pleasure from pain), the third appears to render the consent of a participant in a sadomasochistic encounter invalid, if the harm sustained is significant physical injury. Given the departure from the language used in the earlier cases, Kellam JA does not make it clear what is meant by 'significant physical injury' or whether this would be as low as the limit of $\mathrm{ABH}$ imposed by the cases from England and Wales. As the case concerns manslaughter, we do not gain any further insight into what is meant by this wording.

In any event, Kellam JA, reluctant to open the gates closed by Brown, declined to categorise sadomasochism as a special exception. Although no firm Australian authority has been set down, Stein and McIntosh indicate the likely adoption of Brown in Australia. In South Australia, however, no case law has been decided on point, although the CLCA may provide a helpful starting place.

$43 \quad R v$ McIntosh [1999] VSC 358 (3 September 1999).

$44 \quad R v$ Macintosh [1999] VSC 358 (3 September 1999), [11] - [13] (Vincent J); $R v$ Stein (2007) 18 VR 376, 366 (Kellam JA). For the Canadian reference, see $R v$ Welch (1995) 43 CR $\left(4^{\text {th }}\right) 225$. 


\section{SOUTH Australian LEGISLATION}

In South Australia, the CLCA deals with assaults in Division 7, and with 'causing physical or mental harm' in Division 7A. In Division 7A the issue of consent as a defence to recklessly or intentionally causing harm and serious harm is governed by s 22(3), which states: 'a person may consent to harm (including serious harm) if the nature of the harm and the purpose for which it is inflicted fall within limits that are generally accepted by the community.' Section 22(3) then goes on to provide a number of examples that outline some circumstances in which the conduct will generally be accepted by the community, namely: religious acts, therapeutic procedures, controlling fertility and sport. However, the application of s 19A of the Acts Interpretation Act 1915 (SA) to the CLCA provision means that this list is not exhaustive.

The Division 7A provision departs from the common law approach in England and Wales and does not restrict the defence to a discrete list of activities. The question of policy in determining which acts are generally accepted is crucial. ${ }^{45}$ In enacting the legislation, parliament allotted to the court the task of determining the threshold at which consent may be recognised as a defence. The Attorney-General did note that there is a limit at which consent will afforded no recognition, but, crucially, failed to identify what that limit was. ${ }^{46}$

Ultimately, s 22(3) of the CLCA compels the courts to assess the availability of consent as a defence on a case-by-case basis, and abandons the earlier approach of setting a level of harm and then adding categories of exception. In determining whether s 22(3) will allow consent to be raised as a defence to sadomasochistic conduct causing harm and serious harm, we must therefore answer the deceptively simple question: does the "nature of the harm and the purpose for which it is inflicted' in a particular sadomasochistic encounter 'fall within limits that are generally accepted by the community'?

45

David Caruso et al, South Australian Criminal Law Review and Critique (LexisNexis, $1^{\text {st }}$ ed, 2014), 233

46 South Australia, Parliamentary Debates, House of Assembly, 22 October 2003, 586 (Michael Atkinson). 


\section{ACCEPTANCE OF SADOMASOCHISM}

Traditionally, sadomasochism has not been a sexual practice regarded favourably by society. It has been subject to the same condemnation which was, and still is, faced by other forms of sexual individuality, most notably homosexuality, prostitution and transvestism. ${ }^{47}$ This wider social attitude of condemnation has been well documented overseas; ${ }^{48}$ for example, 37.5 per cent of participants in a survey undertaken in the US by the National Coalition for Sexual Freedom responded that they had been discriminated against on the basis of their sadomasochism. A similar approach has also been taken by psychiatric authorities, ${ }^{49}$ who have diagnosed sadomasochism historically as a disorder of sexual development.

The results of a study undertaken by the University of New South Wales published in 2008, showed that in Australia, 1.8 per cent of sexually active people had been involved with sadomasochism in the previous year, ${ }^{50}$ a fact which Theodore Bennett suggests makes it 'clear that sadomasochistic activities comprise a significant aspect of the Australian sexual repertoire, and means that the 'issue has more than merely hypothetical value'. ${ }^{52}$

The study undertaken by Richter et al looked not only at the prevalence of sadomasochism, but also at the psychological motivation for the derivation of pleasure from pain. They note that medicine has long seen sadomasochists as 'damaged'. ${ }^{53}$ The findings of the study suggested the polar opposite to these long held beliefs; the authors concluded that sadomasochism is 'simply a sexual interest or subculture attractive to a minority' and 'is not a

47 Gayle Rubin, 'Thinking Sex: Notes for a Radical Theory of the Politics of Sexuality' in Henry Abelove, Michele Aina Barale and David Halperin (eds), The Lesbian and Gay Studies Reader (Routledge, 1993) 3, 12-15.

Susan Wright, Second National Survey of Violence and Discrimination against Minorities, National Coalition for Sexual Freedom, 200

$<\mathrm{https} / /$ ncsfreedom.org/images/stories/pdfs_BDSM_Survey/2008_bdsm_survey_analysis_f inal.pdf $>$.

49 See generally, Margaret Hanly (ed), Essential Papers on Masochism (New York University Press, 1995).

50 Juliet Richters et al, 'Demographics and Psychological Features in Bondage and Discipline, 'Sadomasochism' or Dominance and Submission (BDSM): Data from a National Survey' (2008) 5 Journal of Sexual Medicine 1660.

51 Theodore Bennett, 'Sadomasochism under the Human Rights (Sexual Conduct) Act 1994' (2013) 22 Sydney Law Review 541, 543.

52 Ibid.

53 Richters, above n 50, 1660-1661. 
pathological symptom of past abuse' or related to any difficulty in deriving pleasure from 'normal sex' ${ }^{54}$ This was consistent with conclusions drawn by many other empirical studies. ${ }^{55}$ Such findings have been replicated more recently in the United States, where the Diagnostic and Statistical Manual of Mental Disorders published by the American Psychiatric Association noted that a disposition for pain-induced sexual pleasure, in and of itself, cannot be said to be indicative of any mental disorder. ${ }^{56}$ The same manual also urged psychological practitioners to not be so disposed to finding such a connection between sadomasochistic conduct and any mental disorder.

For these reasons, Bela Catterjee views sadomasochism as being 'on the cusp of a new understanding' and as having reached a 'critical juncture'. ${ }^{57}$ Indeed, many sadomasochists view their identification as analogous to identifying as homosexual, ${ }^{58}$ with many in the sadomasochist community urging that sadomasochism should be considered as a legitimate form of 'sexual citizenship,' 59 a term which Diane Richardson uses as a convenient description for the rights and duties which bestow sexual freedom on citizens. ${ }^{60}$ These factors signpost a significantly increased understanding and acceptance of sadomasochism since the decision in Brown and, as a result, the diminishment of the force attributed to Lord Lowry's suggestion in

54 Ibid 1668.

55 See Niklas Nording et al, 'The Prevalence and Effects of Self-reported Childhood Sexual Abuse among Sadomasochistically Orientated Males and Females' (2000) 9 Journal of Child Sex Abuse 53; T S Weinberg, 'Sadomasochism and the Social Sciences: A Review of the Sociological and Social Psychological Literature' (2006) 50 Journal of Homosexuality 17; N K Sandnabba et al, 'Demographics, Sexual Behaviour, Family Background and Abuse Experiences of Practitioners of Sadomasochistic Sex: A Review of Recent Research' (2002) 17 Journal of the College of Sexual and Relationship Therapists 39.

56 American Psychiatric Association, Diagnostic and Statistical Manual of Mental Disorders (American Psychiatric Publishing, $5^{\text {th }}$ ed, 2013) 816.

57 Bela Bonita Catterjee, 'Pay $v$ UK, the Probation Service and Consensual BDSM Sexual Citizenship' (2012) Sexualities 739, 740.

58 Gary Taylor and Jane Usher, 'Making Sense of S\&M: A Discourse Analytic Account' (SAGE Publications, $1^{\text {st }}$ ed, 2001).

59 Darren Langdridge, 'Voices from the Margins: Sadomasochism and Sexual Citizenship' (2006) 10 Citizenship Studies 373.

60 Diane Richardson, 'Constructing Sexual Citizenship: Theorizing Sexual Rights' (2000) 20 Critical Social Policy 105, 107. She concludes by offering 'a way of understanding sexual citizenship as a system of rights, which includes a concern with conduct, identity and relationship-based claims': 128. 
Brown; that sadomasochists wish to satisfy a 'perverted and depraved sexual desire'. ${ }^{61}$

Acceptance of sadomasochism in society has also been replicated in popular culture, where the popular 50 Shades of Grey ${ }^{62}$ ('50 Shades') series has sold over one hundred million paper copies and performed well in the box office. ${ }^{63}$ Notwithstanding its debatable inaccuracies relating to the portrayal of sadomasochistic relationships without true and free consent, 50 Shades has nevertheless highlighted society's willingness to accept sadomasochism. 50 Shades not only discusses the issue of sadomasochism but positively promotes and glorifies the relationship. ${ }^{64}$ Given its popularity, it is possible to argue that for many readers, these relationships and these sexual practices are acceptable. $^{65}$

As the understanding, prevalence and therefore acceptance of sadomasochism increases in society, it becomes increasingly difficult to distinguish between sadomasochism (in nature and result), from the other established exceptions. This is well highlighted by comparison with boxing, where consent has been held to be a valid defence. ${ }^{66}$ If social utility is the doctrine underlying the validity of such activities, then consistency requires that the same logic should apply to sadomasochism. To sadomasochists, violence (or the application of force to the body) is exerted for the meaningful pursuit of sexual pleasure, 'analogous to that of (permitted) rough physical interaction in contact sports' ${ }^{67}$ This inconsistency is exemplified

$R v$ Brown [1994] 1 AC 212, 233

62 E L James, 50 Shades of Grey (Vintage, 1 $1^{\text {st }} \mathrm{ed}, 2011$ ) ('50 Shades').

63

Kristen Acuna, The '50 Shades of Grey' Phenomenon (5 September 2013) Business Insider $<$ http://www.businessinsider.com.au/50-shades-of-grey-by-the-numbers-2013-9?op=1>.

64

The author refers strictly to the acceptance of the sadomasochistic aspect of the relationship, noting the myriad of attacks made on 50 Shades by sadomasochism advocates, who have not only labelled it as misrepresenting the free and safe nature of true sadomasochism, but who have also criticised its glorification of a relationship characterised by domestic violence and manipulation.

65 However, the level and nature of the sadomasochism in 50 Shades is an entirely different factual matrix from the extremity of the activities in Brown; an acceptance of 50 Shades might show an acceptance of sadomasochism in principle, but perhaps not to the extent of the harm in Brown. Furthermore, it should be noted that a reader's enjoyment of a fictional portrayal of certain activities does not necessarily prove that the reader approves of such conduct. I am grateful to Ian Leader-Elliott for this latter point.

66 Pallante v Stadiums Pty Ltd [1976] VR 331 (9 April 1975).

67 Nicholas Bamforth, 'Sado-masochism and Consent' [1994] 57 Criminal Law Review 661, 663. 
when sadomasochism is compared to Mixed Martial Arts cage fighting, where the harm sustained can often be much more severe than boxing. The comparison with piercing, which is protected under the $R v$ Wilson doctrine, also points up an inconsistency. As detailed at length by Mike Presdee, genital piercings have become increasingly commonplace in society. ${ }^{68}$ Genital piercings represent not only an embellishment of the body, but significantly increase corollary sexual gratification. ${ }^{69}$ Plainly, it is uncontroversial that boxing and piercing are not violent for their own sake, but are the means of pursuing socially acceptable and beneficial ends. The increased importance of maintaining bodily autonomy has legitimised the pursuit of sexual gratification and sexual self-determination and, I would argue, also suggests that sadomasochism could be seen as a proportionate and reasonable means in pursuing this end.

\section{SADOMASOCHISM UNDER THE HUMAN RIGHTS (SEXUAL CONDUCT) ACT $1994(\mathrm{CTH})$}

Of some potential applicability to the issue of sadomasochism is the Human Rights (Sexual Conduct) Act 1994 (Cth) ('HR Act'), particularly s 4(1), which states:

Sexual conduct involving only consenting adults acting in private is not to be subject to, by or under any law of the Commonwealth, a State or Territory, to any arbitrary interference with privacy within the meaning of Article 17 of the International Covenant on Civil and Political Rights.

Simon Bronitt has argued that this provision was likely to extend to sadomasochistic conduct. ${ }^{70}$ This was more recently considered by Theodore Bennett, ${ }^{71}$ who views s $4(1)$ as requiring three elements: (1) must constitute 'sexual conduct'; (2) involve only 'consenting adults'; and (3) occur 'in private'. ${ }^{72}$ Presdee, 'Cultural Criminology and the Carnival of Crime' (Routledge, $1^{\text {st }}$ ed, 2002) 96.

69

70

Simon Bronitt, 'The Right to Sexual Privacy, Sado-masochism and the Human Rights (Sexual Conduct) Act 1994 (Cth)' (1995) 2(1) Australian Journal of Human Rights 59; Simon Bronitt, 'Legislation Comment: Protecting Sexual Privacy under the Criminal Law Human Rights (Sexual Conduct) Act 1994 (Cth)' (1995) 19 Criminal Law Journal 222.

71

72

Ibid 547 


\section{A Sexual Conduct}

As noted by Bennett, ${ }^{73}$ the HR Act does not expressly define what sexual conduct is. In Cannavan v Lettvale Pty Ltd, ${ }^{74}$ however, the Queensland Court of Appeal adopted the definition given in the Explanatory Memorandum of any 'physical expression of sexual desire'. ${ }^{75}$ The same Memorandum expressly stated that it would not affect laws which dealt with incest, sexual conduct with intellectually disabled people, bestiality, prostitution, professional misconduct, child pornography or sexual conduct in prison. ${ }^{76}$ As Bennett notes, ${ }^{77}$ sadomasochism is notably absent from this list, suggesting that there was no legislative intention to exclude it from the operation of the Act.

It is likely that given its plain and ordinary meaning, 'sexual conduct' will capture sadomasochism. This was substantiated in Mosley v News Group Newspapers Ltd, in which the Court decided that undercover video-recording of sadomasochism violated the victim's right to privacy and addressed sadomasochistic activities as 'sexual conduct'. ${ }^{78}$

\section{B Consenting Adults}

The Explanatory Memorandum suggests that s 4 does not apply to 'conduct involving children or non-consensual conduct'. ${ }^{79}$ As Bennett notes, this consent was limited in Griffiths $v$ Rose ${ }^{80}$ to occasions where the consent given is 'meaningful'. ${ }^{81}$ As noted by Wiseman, sadomasochist encounters are often limited by the pre-agreed limits of the participants in that encounter, often including a 'safe word'. ${ }^{82}$ For this reason, many sadomasochistic

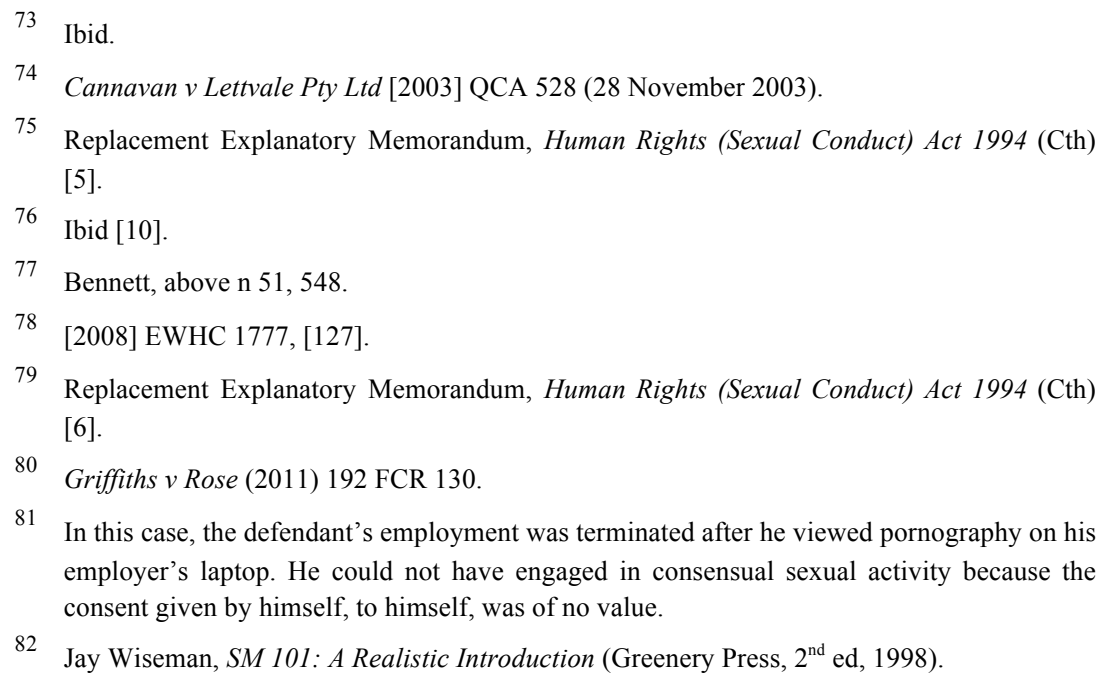


encounters will fall within the element of 'consenting adults'. It is clear, however, that encounters which extend beyond the consent of the parties will not be afforded protection. ${ }^{83}$

\section{$\mathrm{C}$ In Private}

As Bennett notes, ${ }^{84}$ the concept of privacy is an idea which is problematic ${ }^{85}$ and has been the 'site of semantic battles between rival conceptions and interpretations, ${ }^{86}$ When tasked with interpreting the provision, the Supreme Court of Queensland in $R v$ Marchant $^{87}$ merely held that something that is private is 'in contrast to something which happens in public, and something which happens in a place to which there is public access' ${ }^{88}$ When the European Court of Human Rights considered the issue in Pay $v U K,{ }^{89}$ it took a significantly broader approach, finding that notwithstanding the lack of an exclusively private forum, the conduct under consideration still took place 'in private'. This, however, was based on an interpretation of art 8 of the European Convention on Human Rights, which protects respect for '[a person's] private and family life' rather than acts which occur 'in private', and adopts a broader approach than under the Commonwealth HR Act. ${ }^{90}$

Therefore, sadomasochistic acts which take place in clubs and public venues are unlikely to be afforded any protection, while acts such as those in Brown that occur in private residences, are likely to be considered 'in private.'

\section{Arbitrary Interference}

It appears that sadomasochism, in certain circumstances, is capable of protection from 'arbitrary interference' under s 4 of the HR Act. The question therefore needs to be answered: what is arbitrary interference? The right to

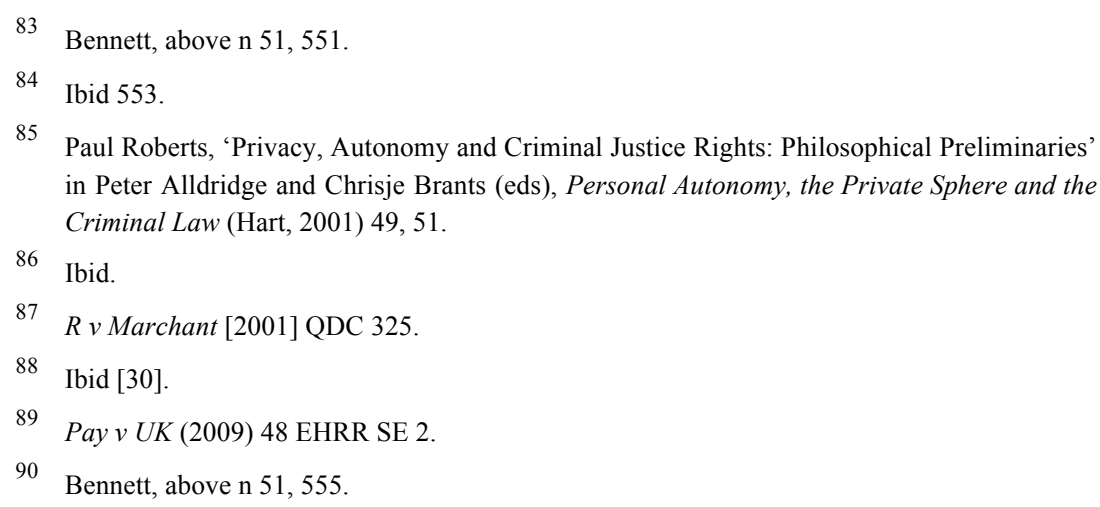


privacy is not 'absolute or unlimited'. ${ }^{91}$ However, 'interference provided for by law must be justified and reasonable in the circumstances'. ${ }^{92}$ Ultimately, 'any interference with privacy must be proportional to the end sought and be necessary in the circumstances of any given case. ${ }^{, 93}$

Bennett identifies two potential grounds for interference with the right: morality and public health concerns. ${ }^{94}$ As discussed at length in Part IV, any law to restrict sadomasochism on the basis of its 'immorality' is likely to be arbitrary; even the ECHR has noted that sadomasochism has become increasingly accepted in British society. ${ }^{95}$ Concerns of sadomasochists spreading their cult and tearing at the fabric of society's morality, are comparable to claims made in the efforts to criminalise homosexuality in earlier decades. ${ }^{96}$ On the issue of interference on the basis of public health, the Lords in Brown noted that the particular sadomasochistic activities in that case gave rise to the risk of infection of cuts, Urinary Tract Infections and HIV/AIDS. ${ }^{97}$ The regulation of conduct for the legitimate concern of public health is one which has been recognised as not being arbitrary. ${ }^{98}$ The question must be answered: at what level of regulation will laws restricting sadomasochism no longer be considered arbitrary? ${ }^{99}$

In Brown the limit was clearly cast as assault occasioning actual bodily harm. This limit would render conduct such as light whipping, which causes mere visible welts and minor discomfort, unable to be consented to. As Bennett argues, to assert that activities such as this carry any conceivable risk of serious injury is absurd. ${ }^{100}$ Not every sadomasochistic encounter can be

Replacement Explanatory Memorandum, Human Rights (Sexual Conduct) Act 1994 (Cth) [9].

92

Human Rights Committee, General Comment No 16: The Right to Respect of Privacy, Family, Home and Correspondence, and Protection of Honour and Reputation (Art 17), $32^{\text {nd }}$ sess (4 August 1988) [4].

93 Human Rights Committee, 'Individual Communication under the Optional Protocol to the International Covenant on Civil and Political Rights', Communication to the Human Rights Committee in Toonen v Australia, 4 April 1994, CCPR/C/50/D/488/1992.

94

Bennett, above n 51, 558

95 Pay $v$ United Kingdom (2009) 48 EHRR SE 2 [26].

96

Bennett, above n 51, 560.

97

$R v$ Brown [1994] 1 AC 212, 236, 255-256, 274.

98 Laskey $v$ United Kingdom (1997) 24 EHRR 39 [43].

99

Bennett, above n 51, 561.

100

Ibid 562. 
analogised with the extremely dangerous activities in Brown; ${ }^{101}$ any interference which takes a blanket approach against sadomasochism is clearly arbitrary. In light of the relatively minor harm that can be sustained during actual bodily harm, it is apparent that this too, would be too low a threshold at which to restrict consent without offending s 4 of the HR Act. However, it remains 'doubtful whether the federal sexual privacy shield could be invoked $\ldots$ in cases where the infliction of significant injury occur' ${ }^{102}$ Therefore, although sadomasochism is likely to be federally protected by the HR Act, even before the operation of any state legislation, it is unlikely that it will be capable of providing protection to those who suffer injuries comparable in severity to those in Brown. However, this is not the case in South Australia.

In South Australia, s 22(3) of the CLCA bridges the gap left open by the $H R$ $A c t$ by expressly providing that a person may consent even to 'serious harm' as long as the purpose for which it is inflicted falls within what is generally accepted in the community. I have argued that sadomasochism is more than likely generally accepted in the community; consequently, I suggest that $\mathrm{s}$ 22(3) would therefore allow consent as a defence to charges under Division $7 \mathrm{~A}$ of causing serious harm arising from consensual sadomasochistic encounters. The CLCA defines 'serious harm' as harm that endangers a person's life, results in serious and protracted impairment of a physical or mental function, or results in serious disfigurement. ${ }^{103}$ Therefore, the CLCA appears not only to live up to Australia's obligations under the HR Act, but also to go a step further in protecting activity of equal and greater severity than the factual matrix of Brown.

\section{CONCLUSION}

Sexuality is a 'fundamental aspect of being human'. ${ }^{104}$ Although all empirical evidence demonstrates that sadomasochism is attractive only to a minority of Australians, significant numbers of Australians nevertheless rely on the legality of their conduct to enable them to express what is 'a fundamental aspect' of their humanity. Sadomasochism, along with homosexuality and transvestism, is no longer labelled as the taboo practice that once it was. As

\footnotetext{
101 Mosley [2008] EWHC 1777, [116].

102 Simon Bronitt and Bernadette McSherry, Principles of Criminal Law (Thomson Reuters, $3^{\text {rd }}$ ed, 2010) 621.

103 Criminal Law Consolidation Act 1935 (SA), s 21.

104 Ignacio Saiz, 'Bracketing Sexuality: Human Rights and Sexual Orientation - A Decade of Development and Denial at the UN' (2004) 7(2) Health and Human Rights 51, 66.
} 
the psychology of the behaviour is better understood and its prevalence in popular culture increases, so too does its social acceptance. In 2015, sadomasochistic tendencies are no longer seen as the satisfaction of the depraved sexual desire as they were in Brown, but rather as a mere subculture attractive to a minority of citizens who do not necessarily suffer from psychological deficiencies.

To serve their purpose effectively, human rights ought not to be restricted to situations where the activity they protect is socially popular or enjoyed by the majority. ${ }^{105}$ The right to privacy is no exception to this. The value of privacy has continued to grow in importance over time, and this growth has driven the calls for giving increased protection to adults who freely consent to sexual conduct in private. This right, conferred by the HR Act, is likely to protect sadomasochistic conduct which does not exceed the mutual consent of the parties and is carried out in private, free of arbitrary interference. It is likely to extend even to acts occasioning 'serious harm' in South Australia but is still likely to be restricted to the threshold of what was, when Brown was decided, $\mathrm{ABH}$, in the rest of Australia.

Ultimately, it appears that the moral and legislative developments of the $21^{\text {st }}$ century, the increased utility of sexual gratification discernible by society and the increased social acceptance of sadomasochism, have conferred two certainties upon those who engage in sadomasochism. Firstly, these developments have rendered it possible for consent to be raised and accepted as a defence to charges under Division 7A of causing harm (s 24) or even serious harm (s 23) arising from sadomasochistic conduct. Secondly, even if a defence under the $C L C A$ fails, it is likely that the courts and legislature would be restricted by the HR Act from making any determination or enacting any law which arbitrarily interferes with consenting adults who practice sadomasochism in private.

105 Aaron Fellmeth, 'State Regulation of Sexuality in International Human Rights Law and Theory' (2008) 50 William and Mary Law Review 797, 904. 